the concrete wall of the tunnel, in both west and east sections, at intervals of 20 metres, and their displacements were measured on six occasions, the last four series (on Feb. 5-12, March 3-9, April 13-18, and July 18-24, 1931) being the most accurate. Though the changes are very minute, the curves that represent the displacements are remarkably similar. It is interesting also to notice that the principal changes occur in the sections crossed by faults or in which the strata suddenly change in strength, such weak lines forming the boundaries of crust-blocks.



FIG. 1.

It has long been known that an earthquake may be destructive on the surface ground while, in a tunnel below, it mav pass almost, or quite, unnoticed. Mr. N. Nasu has recently provided us with some useful measurements on this subject (Bull. Res. Inst. Earthq., vol. 9, pp. 454-472, 1931). During the Idu earthquake, a few cracks were made in the walls of the Tanna tunnel. Otherwise it was unharmed, though in a village above, 55 per cent of the houses were destroyed. Mr. Nasu placed two similar seismographs, one in the tunnel and the other on the ground above, the rock being of the same nature at both places. During the six months that followed, fourteen strong or moderately strong shocks were recorded.
If the period of the vibrations was less than one second, the amplitude was always more than twice, in one case 4.8 times, as great on the surface as in the tunnel. If, however, the period was as much as 4 or 5 seconds, the amplitudes at both stations were almost exactly equal.

Prof. Imamura and Mr. Kodaira have described some seiches that were observed in the lake of Asino-ko in the northern part of the epicentral area shown in Fig. 1 (Japan J. Astr. Geoph., vol. 9, p. 115-125; 1932). The lake runs nearly north and south and is about $3 \frac{3}{3}$ miles long. The limnograph near the southern end of the lake was thrown out of action by the earthquake at 4.3 A.M., but at 7.20 A.M., when it was repaired, seiches of unusual size were recorded, the amplitude at 9 A.M. being $3.5 \mathrm{in}$. and the period 6.68 min., showing that the seiches were binodal. On several other occasions, seiches were observed, usually on the days preceding swarms of earthquakes, for example, on Nov. 16, 19, and 20 , when the numbers of fore-shocks on the following days were 64,530 , and 624, and on Dec. 1, 6, and 9, the numbers of aftershocks on the following days being 240,286 , and 592 . The authors suggest that the seiches were caused by tiltings of the ground, which are known to precede the occurrence of earthquakes.

The tilting of the ground under different conditions is well illustrated in two recent papers (Bull. Earthq. Res. Inst., vol. 10, pp. 130-144 and 145-170;1932). In both cases, the instruments used were horizontal pendulums known as Ishimoto tiltmeters. Mr. W. Inouye describes the movements at the observatory of Mt. Tukuba. The short-period fluctuations, as well as the daily and seasonal variations, are connected with changes in air temperature, an increase in which causes a decrease in the inclination of the mountainside. Earthquakes generally occurred when irregular fluctuations of short period interrupted the long period variations or when the directions of the earth-tilts were changing. Observations of earth-tilts were made at Ito and Kawana in the Idu peninsula from March 19 until July 12, 1930, in connexion with the swarm of earthquakes at Ito during the spring of that year. Mr. R. Takahasi shows that the tilts observed at Kawana must be attributed to changes in the tidal load, though there is some discordance, for which it is difficult to account, between the directions of the observed and calculated tilts.

\title{
The British Iron and Steel Industry
}

AMONG the great industries of Britain which are suffering most from the abnormal conditions of trade is the iron and steel industry, regarding which, for various reasons, many erroneous views are held. The basic facts and circumstances of the industry are described by Prof. W. A. Bone in an article in Chemistry and Industry for April 8, entitled "A Survey of the British Iron and Steel Industry, 1913 to 1929 and 1930-31". Referring first to a misleading view expressed in an editorial in the Observer for Dec. 6 last, on the changes in the relative position of the iron industry in the United States, Germany, France, and Great Britain, and the effects of fiscal policy, Prof. Bone says, "The truth is that the changes so indicated have inevitably resulted from natural causes com. bined with human invention and post-War territorial changes, quite independently of any fiscal conditions, and that no change in our fiscal policy can or will prevent the natural course of events".

The supersession of puddled iron by Bessemer and open-hearth steel, the opening up of immense deposits of iron ore in America, the working of the 'basic' process in Germany, the retrocession of Lorraine to
France, and the comparative leanness of the iron ores of Britain are all factors which have led to other countries outstripping us as makers of iron and steel. Smelting and steel manufacture are, however, but two stages in the production of such things as railways, ships, bridges, and motor cars, and the really important question is: Which will pay us best to make, iron and steel or articles from partly imported materials ?

Surveying the last nineteen years, Prof. Bone deals in turn with (1) production in 1913 and 1929 ; (2) a valuation of British iron and steel outputs in 1929 ; (3) imports of iron and steel raw materials and products in 1913 and 1929 ; (4) exports of iron and steel materials and products; (5) the slump since 1929 ; and concludes with some general considerations. In a series of valuable tables, he gives both the tonnage and the value of imports and exports, and from these it is seen that in 1913 the value of all the iron and steel products and manufactures exported from Great Britain was $£ 111,775,000$, the value of the corresponding imports was $£ 36,175,000$, leaving a balance in our favour of $£ 75,600,000$. The corresponding figures for

No. 3264, VoL. 129] 
1929 were $£ 160,930,000, £ 60,304,000$, and $£ 100,626,000$. In 1929 the slump set in, affecting all the main iron and steel producing countries alike, and the world production of steel fell from 118,300,000 tons in 1929 to $93,330,000$ in 1930 and $69,590,000$ in 1931 . In the United States, with its high tariff, the fall was no less than 54 per cent. At the conclusion of his survey, Prof. Bone remarks that, "in view of the foregoing facts, which demonstrate beyond dispute not only how great has been the value of our vast export trade in iron and steel commodities within recent years, but also the ineffectiveness of tariffs to protect a country against the effects of a world-wide 'slump', the Government may well hesitate about adopting any measures calculated to raise steel prices to home consumers". " "Some temporary measure of relief may be necessary to tide over the present emergency, but such measures should be safeguarded so that the dependent export industries shall not suffer through enhanced prices."

\section{The Plant in Relation to Water*}

THE study of plant life in arid regions has more than 1 an academic interest. It throws important light on the relation of plants in general to their water supply. All things being equal, the plant is most valuable to man either as a crop or as forage when it gives the greatest yield with the least expenditure of water.

An arid region is not constantly hot and dry. It is one of extremes of climate. Plants growing there are not always faced with water shortage; at times they have enough and to spare. Nor are they always growing under a high temperature; extremes of cold have to be met as well as heat. The plants growing in dry regions are not of uniform type but very varied. A large proportion of the species are not drought resistant at all, and grow flowers during occasional dry spells, then die off. The succulent type, familiar through the cacti, with great stores of water which they expend very slowly, are peculiar and very rare in the natural flora of many dry countries. In Australia they are practically absent, and it is only a strictly limited area of light rainfall country that is threatened by the pest pear, not the great arid areas in South, Central, or Western Australia. The seriousness of the prickly pear is its menace to land that is good pastorally, not the danger to the more arid parts.

The various hard-leaved shrubs and trees of the dry country flora are plants of a type suited to climatic extremes. A curious feature of the Australian flora is that the shrubs and trees over most of the continent are of the hard-leaved type. This is the case even in the Sydney district, where the rainfall is good and the loss by evaporation annually is less than the rainfall. The hard-leaved structure does not mean that these plants are necessarily economical of water all the time, but that they can undergo more or less prolonged dry periods without injury.

In studying the drought resistance of various crop and fodder plants, some surprising results have emerged so far as the water requirements are concerned; thus, lucerne is about three times as lavish with its water as is sorghum in order to produce the same weight of dry material. The fact is that no single basis for drought resistance is known. The success or failure of a plant for economic purposes cannot be judged by its economical use of water alone. Even more important is its ability to remain active while water is running short and to survive dry spells.

* From the presidential address to the Linnean Society of New South *ales delivered by Prof. T. G. B. Osborn on March 30.

\section{University and Educational Intelligence}

CAMbridge.-Dr. G. P. Bidder has given 5000 lire, with the promise of a like sum next January, for the benefit of the occupants of the Cambridge table at the Zoological Station at Naples.

Mr. N. F. Mott, of Gonville and Caius College, has been appointed University lecturer in the Faculty of Mathematics.

The General Board has, on the recommendation of the Faculty Board of Mathematics, conferred the title of Stokes lecturer in mathematics on Dr. P. A. M. Dirac.

Dublin.--Dr. T. J. Nolan, State Chemist, Irish Free State, has been appointed professor of chemistry in University College, Dublin. Dr. Nolan took over his new appointment on May 1.

MANCHESTER.-The honorary degrees conferred at the commemoration of Founders' Day included the following :-D.Sc.: Sir James Jeans; LL.D.: Lord Rutherford, Sir Arthur Salter, and Dr. W. D. Ross.

OxForD.-The preamble of the statute establishing a final honour school of geography was moved in Congregation on May 10 by $\mathrm{Mr}$. C. G. T. Morison, student of Christ Church, and carried without a division. Mr. Morison laid stress on the necessity of an adequate scientific equipment for candidates in the school, with the view of providing which many different bodies have had to be consulted. The establishment of this examination will remove certain disadvantages under which graduates of Oxford have suffered in comparison with those of other universities.

THE Rockefeller Foundation, New York, U.S.A., has published the twentieth series of "Methods and Problems of Medical Education". It deals with many departments of study in medical schools in all parts of the world. The volume contains a number of admirable illustrations of the buildings and laboratories described, in many cases accompanied with plans to scale. The articles are not copyrighted, and may be reprinted or utilised in any manner without permission.

THe first award of the Swan Memorial Scholarship, established as a national memorial to Sir Joseph Wilson Swan, will be made this year by the council of the Institution of Electrical Engineers. The Swan Memorial Fund, the interest from which is devoted to the scholarship, was subscribed through the initiative of a committee composed of representatives of the County Borough of Sunderland, which was Swan's birthplace, and the Institution of Electrical Engineers. The scholarship has an approximate value of $£ 140$, and is tenable for one year. Candidates must be British subjects, less than twenty-seven years of age on July 1, and preference will be given to those associated with the County Borough of Sunderland. Awards of the following scholarships will also be made this year :-Duddell Scholarship : annual value $£ 150$ for three years, age limit, nineteen years; Ferranti Scholarship, annual value $£ 250$ for two years, age limit, twenty-six years; Silvanus Thompson Scholarship, annual value $£ 100$ and tuition fees, age limit, twenty-two years, for two years, for works employees. Applications (specifically mentioning the name of the scholarship) for particulars of any of these scholarships should be addressed to the Secretary of the Institution, Savoy Place, London, W.C.2.

No. 3264, VoL. 129] 